Archaeological Journal

\title{
Sens and Auxerre
}

\section{Edward A. Freeman}

To cite this article: Edward A. Freeman (1882) Sens and Auxerre, Archaeological Journal, 39:1, 97-116, DOI: $10.1080 / 00665983.1882 .10852027$

To link to this article: http://dx.doi.org/10.1080/00665983.1882.10852027

$$
\text { 曲 Published online: 14 Jul } 2014 .
$$

Submit your article to this journal ¿

Q View related articles $₫$ 


\title{
The Arrbaeological Fournal.
}

\author{
JUNE, 1882 . \\ SENS AND AUXERRE. \\ BY EDWARD A. FREEMAN.
}

The cities of central Gaul are in some points less historically attractive than those which lie either to the north or to the south of them. The whole northern range, from Flanders to Britanny, is so closely connected with the history of our own island that the British or English historian counts them as coming within his immediate domain, as forming part of the necessary range of his own story. In a large part of southern Gaul this special insular connexion applies also, while there is a wider interest bearing on the general history of the world. Aquitaine and the Imperial Burgundy may for some ages pass almost as an expansion of Italy. The earlier stages of the revolutions which brought modern Europe into being were wrought at least as largely on Gaulish as on Italian soil. The central lands of Gaul have a smaller share than the lands on either side of them in either of these sources of interest. Their most stirring days come earlier still, when Cresar had to tell the tale of Gergovia, of Bibracte, and of Alesia. In later times they do not stand out in history like the lands around them, east, west, north, or south. There is even a kind of geographical haziness about them. It is harder to say off hand how much in any age belonged to the French kingdom, how much to the Burgundian duchy, how much to smaller powers separate from either, than it is to trace out the better defined bounds of Normandy and Aquitaine. Much of the history of dukes, counts, and bishops seems, at first sight at least, vor. $\operatorname{xxxyx}$ (No. 154) 
to be almost wholly of local importance. Yet these lands and cities have much to show, each for itself; they have many noble monuments, many stirring memories-monuments and memories too which bring us, oftener than might be expected, both into the great world of general history and into the special history of our own island. And the local history itself in each district and city, the story of dulses and counts and bishops and communes, becomes clothed with an interest of its own, as soon as we grasp its thread. Notices which we passed by without heed begin to have a meaning and a charm when we have once seen the place to which they refer, and have learned to clothe it with a kind of personal being. Among these cities I have picked out two for some measure of notice and comparison. I do not profess to be thoroughly master of their history. I write, while still journeying, from my own observation on the spot, and, from such books as I was able to pick up on the spot. At one place I could find no help of this kind at all; at the other I have learned enough to see that the story of Autessiodurum, city, county, and bishopric, might be worth telling at length. But I do not profess to be at home in either of these cities, as I might be at Lincoln or at Le Mans. For Sens and Auxerre do not, like Lincoln and Le Mans, enter into the general thread of English history and of those branches of continental history which cannot be separated from it. Both cities have a certain connexion with things and persons belonging to our own island. But the connexion is incidental only; certain things did happen at certain places, which, as far as one can see, might just as well have happened somewhere else. Still there is a certain pleasure, when one is tracing out all that one can of the history and monuments of distant places, when one lights on so many memories as in this case we do of men who have played some part, one of them a great part indeed, in the history of England. In both the cities of which I am about to speak we stand on soil which has been trodden by the feet of one of whom I may leave others to speak as the martyred archbishop, while I will myself speak of him as the great chancellor who helped his king to give England peace after the nineteen years of anarchy. 
Within the modern department of the Yonne, on either side of the river of that name, lie two of those immemorial cities of Gaul which have lived on through all changes, and from which the traces of their earliest days have never wholly passed away. Their very names teach us the essential difference between the history of Gaul and the history of Britain. We have no name in English topography answering to such a name as Sens; we have next to none answering to such a name as Auxerre. No English city keeps the name of a British tribe, as Sens keeps the name of the Senones, absolutely unchanged save by mere shortening in men's mouths. Here, according to the rule in Northern Gaul, the oldest name of the town itself has vanished; the tribe name only has lived on; Agelincum Senonum, Civitas Senonum, lived on as Senones or Sens. Nor is it much more easy to find in England a town which, like Auxerre, keeps, not indeed a tribal, but a strictly local name, contracted and corrupted as usual, but never exchanged for any other. Old Autessiodurum, in all its many spellings, is but new Auxerre writ large. In England the Roman site often keeps traces of its Roman name ; but it keeps only traces. Isca and Venta survive in Exeter and Winchester; but they are not there in their own presence, as Autessiodurum is still present in Auxerre. The added chester marks no slight difference. It marks that the modern name is not strictly the abiding name of the Roman city, but is rather the name which the conquering Englishmen gave to the Roman city, sometimes only to its site and ruins. Auxerre is Autessiodurum itself; Winchester is rather the chester which had once been Venta. In the like sort, Lincoln, in its unique ending, proclaims to the world that Lindum on the Witham was a colony of Rome, no less than the most abiding, in name at least, of all colonies, the Colony of Agrippina by the Rhine. But, in so proclaiming Lindum as a Roman colony, it proclaims it only by the mouth of the Teutonic conqueror of Lindum, not by that of the representatives of its own Roman colonists. In the case of Eboracum, the Latin name itself was twisted on Teutonic lips,--as Jerusalem was twisted into Hierosolyma on Greek lips,--so as to give it a seeming English meaning in the shape 
of Eoforwic or York. London does indeed come as straight from Londinium as Auxerre comes from Autessiodorum ; but for a long time London itself had to struggle against the prevailing tendency; it narrowly escaped surviving as Londonwick or Londonborough. It was amusing a little time back to see a writer in an English periodical, who evidently meant to be smart, speak of the ancient name of a famous Norman city as "dogLatin" for its modern name. Such smartness revealed an ignorance, an ignorance which might easily have been kept hidden, of the whole difference between the history of Gaul and the history of Britain. The writer evidently thought that Lexovic was a name made out of Lisieusx, as any one who chose might coin. such a name as Bromichamia out of Birmingham, or Northamptonia out of Northampton. In truth the doggishness is all the other way. Lexovia is not "dog-Latin for Lisieux;" but Lisieux might, with very little straining of language, be called "dog-Latin for Lexovia." So Wintonia and Exonia are dog-Latin, though very old dog-Latin, for the purer Latin Venta and Isca. In the like sort, Autessiodurum is not dog-Latin for Auxerre, but Auxerre is dog-Latin--in other words French-for Autessiodurum. In both cases the oldest name, the tribe name at Sens, the local name at Auxerre, still lives on, mutilated indeed by what philologers call phonetic decay, but never exchanged for any other name, never lengthened by any newly added element. In Britain the names would be something like Senchester and Auchester; here they remain Sens and Auxerre. The difference between the two systems of nomenclature is one of the thousand witnesses that, among the endless revolutions which have gradually changed ancient Gaul into modern France, there has been none so sudden and overwhelming as that which, in a moment, turned Britain into England.

Of the two cities by the Yonne, Sens, by keeping the name of the tribe, proclaims itself as the head of the Senones, the centre of their state, in a word as Civitas Senonum. The name of Autessiodurum has given rise to some ingenious local speculation; in a general view of

${ }^{1}$ Step by step, and by very slow steps, if we look to the conquest of the whule land ; lut most truly in a moment, if we look to the conquest of each par. ticular spot. 
things, it is enough that Autricun, Autessio, any of its many forms, are all something else and not Senones. Auxerre was not the head of the nation, and Sens was. It would seem that, even in modern remembrances, the claims of the old Agelincum, in their widest sense, are not forgotten. The Sens of our own day contains a street of Brennus: for the Gauls who encamped on the Roman forum bore the Senonian name; and, even if students of the migrations of nations may be tempted to think otherwise, it cannot be expected that local patriotism should look on the conquerors of Rome as other than direct colonists from the northern home of their race. In the Street of Brennus, within the walls of the Civitas Senonum, it would not do to whisper that the settlement of the Senones south of the Alps may have been as old as their settlement to the north. The dignity of the head of the Senones is still marked in the ecclesiastical position of the city. The church of Sens is still, as of old, a metropolitan church, the head of an ecclesiastical province. Of that province Auxerre was of old a suffragan see; modern arrangements have made the union still closer; Auxerre has lost its separate bishop; its diocese is merged in the arch-diocese of Sens. It may be thought a small thing to have been the metropolis of Auxerre; it is perhaps a more striking thought that, down to the seventeenth century, Sens was, in this same ecclesiastical sense, the metropolis of Paris. It was only at that late date that the church of Paris became an archiepiscopal see; till then her bishop was simply a suffragan of the Archbishop of Sens. Such a seeming anomaly proves more in Gaul than it does in any part of Britain. In Britain, both Celtic and Teutonic, the oldest episcopacy was mainly tribal or territorial; the chair of the bishop was not necessarily fixed in the greatest town in his diocese, nor the chair of the archbishop in the greatest city of his province. That London should be a suffragan see of Canterbury was the natural result of the geographical course which Christianity took in England; it does not prove that Canterbury was, even in the sixth century, a greater city than London. The ecclesiastical subordination of Paris to Sens tells us much more. The ecclesiastical divisions of Gaul so closely followed the 
Roman civil divisions, and the city was so thoroughly the kernel of both, that we may set it down for certain that, when the dioceses of Gaul were mapped out in the fourth century, the city of the Parisii, the dear Lutetia of Julian, counted for less than the city of the Senones. And we accordingly find the Parisii, among other Gaulish tribes, enrolled as members of a confederation of which the Senones were the head. But the later fates of the city of the Parisii and of the city of the Senones have been widely different. Lutetia, Paris, after having seen the headship of Gaul more than once dangled before her eyes, rose at last to that headship by becoming, in the tenth century, the kernel of a new power and a new people. In that character she outstripped all her rivals, rivals which, one by one, were brought within the bounds of the kingdom of which she was more than the head, of which she was rather the cradle, almost the parent. But her ecclesiastical superior could not, except in that mere point of ecclesiastical dignity, be counted among her rivals. Sens may be said to have grown physically since the days when she was the head of the Senones; for she has considerable suburbs outside her Roman walls. Relatively she has gone back. The size and population of Sens are far below those of many French towns which have lived on through all ages as local centres and local centres only. Sens is not even the head of a modern department; the prefect of the Yonne has his seat at Auxerre. The city, in short, would seem to live on the memory of her old greatness, Gaulish and ecclesiastical. Her two most abiding monuments are her metropolitan church and her mighty Roman wall.

Sens then was the ecclesiastical head, as Paris was the temporal head, of France in the very narrowest sense, of the dominions which were held by the Dukes of the French at the moment when they grew into kings. But, for that very reason, neither the metropolitan of Sens nor his suffragan of Paris shared in the highest dignity which belonged to subjects or vassals of the French kingdom. Among the twelve peers of France, six spiritual, six temporal, the prelates of Sens and Paris were not numbered. The primate of Sens was not, in the chain of feudal dignity, the peer of the Archbishop and Duke of Rheims, nor was his suftragan of 
Paris the peer of the Bishop and Duke of Laon. The prelates of Rheims and Laon were in theory the peers of the great temporal princes of Gaul, of the Count of Flanders and the Duke of the Normans. Like them, they held directly of the King as king. But the Archbishop of Sens and the Bishop of Paris held of the Duke of the French, just as the Archbishop of Rouen and the Bishop of Bayeux held of the Duke of the Normans. That the Duke of the French and the King of the French were the same person made no difference in this matter. The vassals of the Duke were not immediate vassals of the King. Rheims therefore remained the ecclesiastical head of the French kingdom, while Lyons remained the primatial see of all the Gauls, both within the French kingdom and beyond its borders. Sens meanwhile was simply the metropolitan see of a province of which the growing capital of the kingdom remained for so many ages a suffragan.

Of the two aspects of Sens, as the ancient city of the Senones and as the see of a long line of archbishops, the ecclesiastical aspect is doubtless the most prominent in the general look of the city, but it is hardly the most striking when we come to a more minute examination. One might almost wish that the Roman wall of Sens stood out, like the Roman theatre of Orange, as the chief object in the view, rather than the towers of the metropolitan church. Of the two cities by the Yonne, the general aspect of the city of secondary rank, the Gaulish oppidum, the suffragan bishopric, is incomparably more striking than that of the head of the tribe and the province. At each point, by the site of Sens and by the site of Auxerre, the broad river flows between ranges of hills of no great height. On its way to join its chief the Seine, the Yonne fittingly shares the tendency of its chief to widen and divide its stream and to embrace islands within its course. But at Auxerre the high ground on the left bank, the western bank, comes down almost close upon the stream, while at Sens the hills keep at some distance. The choice of the site of Sens was clearly determined by the presence of a considerable island, a position important for military purposes, as affording the best means of 
blocking the stream against any enemy. The island was not indeed, as at Paris, itself the city ; but it gave the city its character. It rather reminds one of Meulan, where the Seine was bridged by a series of island fortifications yet more thoroughly than the Yonne was at Sens. Sens therefore is essentially a river city, not a hill city. There is of course some slope from the river's bank, but Sens does not occupy a height; there is no akropolis; the city, planted on the right bank of the river, looks up to far higher ground on the left bank. In the general view of the city itself the two unequal towers of the metropolitan church form the main feature. A church on the distant hill side, another near the river outside the city, one or two other towers within the city itself, come into the general landscape ; but it is the towers of Saint Stephen's which give the city its character at the first glance. The mighty remnant of earlier times which lives to proclaim the other side of the history of Sens has to be looked for; it does not force itself on the eye of the traveller as he first draws near.

At Auxerre, on the other hand, though there are one or two islands not far off, there was none that was large enough to enter into any great scheme of military defence. The western hills moreover came close to the stream. They therefore became the site of the Gaulish stronghold which grew into Autessiodurum. But the heights immediately above the river are not very lofty; they are an advanced range divided by a slight valley from higher hills behind them; they do not form any distinct peaks or broad table land; the whole city slopes down to the river, and the highest points of the hill do not come within the earliest enclosure. Few cities have a more striking general effect than Auxerre as seen at some little distance on the other side of the river. As seen in the very near view, from the bridges or from the other bank, the appearance is perhaps too much that of three great ecclesiastical buildings set in a row. But the majestic outline of two of them, their wonderful shiftings in the different points of view taken in the course of a walk on the other side. can hardly be surpassed. The centre and highest of the three is the cathedral church of Saint Stephen; the protomartyr holds the first place at Auxerre as well as at 
Sens. It is a mighty mass indeed, rising proudly over its subordinate buildings, a church of an outline thoroughly French, short and lofty, with the crossing of its four limbs unmarked by the smallest spire or bellgable; a single tower, one of an unfinished pair, rises at the west end. It is an outline strange to the English, and even to the Norman, eye, but it is an outline which grows upon the beholder. Our first feeling perhaps is that it looks like only half a church; but we gradually feel that it makes a compact and well proportioned whole after its own ideal. To the right, outside the original city, once forming a separate fortress on its own spur of the hill, stands the famous abbey of Saint German, the renowned bishop of the fifth century to whom a large part of the fame of Auxerre is owing. The western part of the nave has perished; the single remaining tower with its spire therefore stands detached, and the general proportion of the building is of course a good deal spoiled. But this loss is hardly felt from those points of view where the east end is seen rising immediately over the river. This east end is one of the very best French type ; the outline of the double apse stands clear, and is not confused, as are some French east ends, by a forest of flying buttresses almost hiding the building itself. Lastly, to the left of the cathedral, the church of Saint Peter, standing on the lowest ground of the three, and as a building not for a moment to be compared to either of the others, is forced as it were into equal terms with them by the great height and stateliness of its single side tower. All three rise with their east ends straight above the river, a noble and wonderful group, but, still a group which, in the near view, suggests the idea of a row of great churches rather than of a city. This feeling is taken away in the somewhat more distant view, say from the railway station. We still lack some counterbalancing object like the castle at Durham; but now we see the whole lie of the city; smaller and more distant objects come in, and we see how low the three great churches really stand, how far they are from covering the highest points of the hill of Auxerre. The highest ground we now see to be covered by the church of Saint Eusebius with its spire; other towers, civic and military, come into sight; unluckily a rather

voL. $x \times x I x$. 
grotesque effect is given to the great civic tower, the strange covering which has supplanted its ancient spire. In the immediate neighbourhood too of this tower, unpicturesque civic buildings have in later times supplanted the ancient castle of the counts of Auxerre, a building whose presence is thoroughly needed both for the general variety of the landscape, and in order to bring out one leading element in the history of the city. Still from this more distant point we see Auxerre itself as a city, and not merely its three great churches. These last still stand as a noble front to the picture, none the worse because the picture itself is filled up with a background not wholly unworthy of them.

It is hardly possible, one would think, that the general aspect of Auxerre should fail to satisfy the highest expectations which can have been formed of it. It is certainly otherwise with the first glance of Sens. The one leading object is the metropolitan church, and the metropolitan church is certainly disappointing. If we lighted on it as the church of some monastery of which we had never heard or of some obscure bishopric of which we knew the name and no more, we should be delighted with such a find. But one expects more from a church of primatial rank, and one which has so long a history as the church of Sens. The whole scale and air of the building seems small and weak for a compeer of Canterbury and York, of Rheims and Rouen and Bourges. Its groundplan would rank in England only with that of our smallest cathedral churches, nor has it the soaring height of Auxerre to bring in the characteristic feature and characteristic merit of the great French buildings. The most striking parts outside are the great rose windows of the transepts, and the two western towers. Of these, the southern is finished in a rich and late style running off into Renaissance; the northern, as it now stands, is not finished at all, having altogether lost the roof which gave it the name of the tower of lead, as distinguished from its fellow, the tower of stone. We go in, remembering the near connexion between Sens and Canterbury, how, in the rebuilding of Canterbury choir after the great fire in 1174 , the fire and the rebuilding which Gervase and Willis have made memorable, the work 
was begun by William of Sens and carried on by William the Englishman. We have heard, and heard with perfect truth, of the influence which Senonese models had on the works of the Senonese architect in another land. But, if we go to Sens with Canterbury in our heads, we are unconsciously led to look for something at Sens which we can measure with Canterbury. And that we shall not find. We shall find columns and capitals of that peculiar type of the latter. part of the twelfth century which came nearer to the old Corinthian models than anything that was seen for some ages before or for some ages after. We are tempted to see in them the works of the Senonese William, before his skill reached its full height at Canterbury. But the church, as a whole, is a good, rather plain, minster of the second or third scale, a characteristic specimen of its age. Its adjunct, which bears the name of the Synodal Hall, is in its own way more striking than the church itself. That is to say, we have many minsters surpassing the minster of Sens: we have few or no vaulted halls of the thirteenth century to rival the hall of Sens.

From the metropolitan church we turn to its suffragan. But it sounds almost like mockery to compare the churches of Sens and Auxerre. That of Auxerre doubtless owes part of its grandeur from without to its imposing site; but it would be a glorious pile, if it stood anywhere. From some points of view, even the lack of its southern tower is not felt; the northern one almost puts on the character of a single western tower. It may be that, from every point but the west, one western tower like that of Alby would really have been the best finish. But the single tower of Auxerre is essentially one of a pair ; it has no claim to compare with Alby or with any of the great single towers; it hardly equals its neighbour at Saint Peter's. The general aspect of Auxerre cathedral is distinctly one which grows upon the beholder; the mass hangs well together, and in the French ideal of a church, the parts have not the same independence which we are accustomed to look for in English minsters. One who is used to the central towers of England and Normandy, to the lantern, massive or soaring, for which the four arms seem to cry as their natural crown is 
sometimes tempted to say that, if the mid-tower is gone, the transepts had better follow it, as at Alby and Bourges. But one gradually gets used to the French grouping, and, without the transepts, there would be no opportunity for the northern and southern portals of Auxerre. The transepts suggest a fair comparison with Sens. Which is to be preferred, the great round windows at Sens, round windows and nothing else, or the pointed windows at Auxerre, with a dominant circle in the head? Perhaps, on the principle of giving the prize to whatever best works out its own idea, we may here give Sens the first place. But, on the whole, if there be any real fault in the general outline of Auxerre, it is the odd fancy which has given the Lady Chapel a square end instead of an apse. Here Saint Stephen is undoubtedly surpassed by his neighbour Saint German.

We enter, perhaps by one of the western doorways, rich with their elaborate sculpture, and we find ourselves in a church which has a distinct form of beauty of its own. Its proportions are altogether un-English, but it has not the almost overwhelming height of Amiens and some other of the greater French churches. But its relative height is very great; a church which, in the groundplan is shorter than Wells, is fully as lofty as Westminster. Mr. Petit remarked long ago that Auxerre cathedral would be better for a few more bays added to its length. In the direct western view we certainly feel this, hardly perhaps from any other point. At a first glance it strikes the eye that the choir has a depressed look, owing to the arch which is used in the vaulting being much less sharply pointed than that which is used in the nave. But this feeling soon goes off, and we come to take in the sterling merits of the building. The whole hangs together; yet the details of the thirteenth century in the choir and those of the fourteenth in the nave are well coupled and contrasted. Each time the church is entered, the satisfaction of the beholder grows. We feel more at home at Auxerre, better able to take in the special beauties of the several parts, than we feel in minsters of the very first rank in point of scale.

I remember standing at the crossing of the cathedral of Le Mans-looking one way to the unsurpassed majesty 
and beauty of the choir built after Maine had lost its separate being-looking the other way to that wonderful nave, built, rebuilt, overlaid, in the best forms of earlier days, by bishops and princes whose deeds have formed no small part of my own studies - and feeling how deep, and yet how different, was the interest of the two parts of that noble and historic church. On the one side was simple artistic beauty, beauty which in its own way could hardly be outdone, but beauty which suggested hardly any thought but that of pure artistic admiration. On the other side, the main interest lay largely in the strictly historical view of art, and, to me at least, yet more in the memories which it called up of the stirring annals of the Cenomanian city and county. Here at Auxerre the feeling is different. It is hard, for an Englishman at least, to clothe the history of the county of Auxerre with the same attraction as the history of the county of Maine; and at Auxerre the charm of all that stands above ground is artistic rather than historical. For anything which brings the cathedral church of Auxerre within the range of even Norman interests we have to go underground. The crypt under the choir is the vestige of a far earlier church, whose building attributed to a somewhat strange character of the first half of the eleventh century, Hugh, Bishop of Auxerre and Count of Challon. The Norman chroniclers delight to tell how, when the Count-Bishop drew on himself the wrath of Duke Richard the Good, he was brought so low that he was glad to make the most abject form of submission. He came to meet the Duke, so Wace tells in his French rime, as William of Jumieges had before told in his Latin prose, with a saddle on his back, that the conquering Norman might, if he would, ride on his lowly servant of Auxerre and Challon. Hugh's work above ground has utterly perished, but his crypt abides. It is such as we might look for in a work which is assigned to the year 1024. Some ancient columns are used up again, but the most part have capitals of those nondescript forms, neither classical nor Norman, which are characteristic of the time. They are the exact fellows of those in the crypt of the cathedral church of Nevers, to which nearly the same date is assigned, 
The church of Sens then can hardly venture to enter into any comparison with the church of Auxerre : but the metropolis has some associations and relics in which the daughter has only a lesser share. Auxerre indeed, then a renowned seat of learning, was, naturally enough, one of the seats of the early studies of Thomas of London at a time when modern romance has daringly sent him to as yet unlearned Oxford. But Sens, one of his shelters in exile, the place where Thomas, no longer of London but of Canterbury, met the Pope for whom he endured so much and who did so little for him, claims a greater share in him than Auxerre. She proudly proclaims her right by displaying, as one of the choicest relics of her treasury, the vestments in which he is believed to have said mass at her altars. One choice object in the same treasury is an exquisite piece of Byzantine ivory work representing the history of Joseph and David, with Greek legends so faint that, as the relic now stands, they have mainly to be taken on faith. Auxerre too has its ancient and graceful treasures, but hardly any that can be set against this. Yet it has one object, which suggests thoughts of quite other kinds, but which comes from the same side of Christendom as the Byzantine ivory. This is a copy of the Gospels in the old Slavonic character. What brought it to Auxerre? There was said to be somewhere in France-hardly at Auxerre-a Slavonic service-book brought in the eleventh century by Anne the Russian wife of the first King Henry. After her death it was kept as a relic; but it never found another reader till, six centuries and a half later, it was shown to Peter the Great. I know not whether any such curious story attaches to the Slavonic book at Auxerre. No one that I saw could tell me anything about it, beyond the suggestion that, in the days when Auxerre drew students from England, it may have drawn them from the Slavonic lands also.

Against the synodal hall of Sens Auxerre might perhaps strive to set the buildings to the east end of the cathedral, once the bishop's palace, now the prefecture. But as they now stand, the comparison is an unfair one. The hall of Sens may be seen inside; the palace at Auxerre has now nothing to show within. Outside, to 
the east, there is a lovely gallery of rich and late Romanesque work, work almost Italian in its gracefulness, which goes by the name of the Bishop's Walk. To compare small things with great, this charming arcade looks down upon the Yonne almost as the sterner cryptoporticus of Diocletian looks down upon the haven of Spalato. But it is in the subordinate churches, even more than in the cathedral, that the great strength of Auxerre lies. Not a few have been swept away ; but the abiding remnant is precious. Sens too has her churches beyond her walls. There is in the island of the Yonne a very pretty little church of much the same date as the cathedral; and the abbey beyond the walls is found outside Sens as well as outside most other cities. But it has to be looked for. It is not set down in Joanne's very useful guide-book, and I must confess that I might not have heard of its being, had I not had, shortly before I went to Sens, found it needful to turn to the chronicle of Sanctus Petrus Vivus-Saint-Pierre-le-vif-otherwise the chronicle of Clarius. The chronicler describes with great delight how, in one of the councils of the reign of Philip the First, his own Archbishop of Sens was set in all things on a level with the Archbishop of Rheims himself, - Saint Peter Vivus-one hardly ventures to translate- had therefore to be found, and found he was, after a rather long walk from the eastern end of the city. The church is singularly small for its purpose, but it is of extraordinary architectural interest. It is a-Romanesque building with a central tower, showing a nearer approach than is usual in these parts to that characteristic feature of the early Romanesque, the mid-wall shafts of Professor Willis' nomenclature. The small columns dividing the windows, set in the centre of the wall, are found in countless churches of Germany, Italy and England-above all in Lindesey, Aquitaine, and the royal Burgundy ; in Normandy and France they are rare. Here, if not the thing itself, yet something unusually like it, is found in this massive tower, central, though without transepts strictly so called. Small and plain as it is, this church is no mean specimen of a rather early Romanesque; but, small and plain, hidden in a paltry suburb, it is, in its general effect, a poor competitor for the magnificent Saint German at Auxerre, rising over the river only less proudly than its 
episcopal neighbour. Here a most graceful, but not very elaborate, church of the earlier French Gothic has had to deplore the loss of the western part of its nave. Thus, as I have already hinted, the one remaining western tower, Romanesque of the twelfth century and crowned with a spire, stands apart like a detached canpanile. It was meant, it would seem, neither to stand apart, nor to be altogether part of the church, but to form one tower of a kind of narthex or great western porch, like that of the cathedral at Autun. Saint German too has his underground wonders, in a crypt yet earlier and more striking than that of Saint Stephen. This crypt shelters a store of columns and capitals, among them one pair especially for which alone the zealous student of the strange forms supplied by the darker days of art might think a journey to Auxerre no unprofitable task.

But Saint German of Auxerre has, for the visitor from Britain of either race, associations wholly distinct from its purely architectural features. It bears the nameindirectly it might be called the work - of the great Bishop of Auxerre of the fifth century, who, like Ambrose, forsook temporal for spiritual rule, and the sphere of whose spiritual labours reached to the island which was presently to become ours. Six hundred years later, Saint German of Auxerre becomes connected with the ecclesiastical history of England. It was a monk of his house who went forth, moved by a vision, to found the house of Saint German by the Ouse, that great minster of Selby, no less splendid in its own way than its parent, though so utterly unlike the mother church in every feature. Nowhere can there be a stronger contrast than there is between the apses of Saint German at Auxerre and that one great east window, noblest save one in England, which ends the choir of Saint German at Selby. And besides Saint German's, there still remain two other notable churches at Auxerre. There is Saint Eusebius, the church that crowns the whole city, a good specimen of the Transitional style, with a side tower of graceful Romanesque, crowned by an octagon with a spire. This is one of those churches in which the architects of the fifteenth, sixteenth, and even seventeenth, century began to rebuild, but commonly-we may say happily- 
never finished their work. There are a crowd of churches in France where a lofty choir of late date, sometimes in pure, though late Gothic, sometimes more or less mingled with Renaissance details, soars above an earlier nave whose rebuilding after the same pattern has been designed but never carried out. So it is at Saint Eusebius at Auxerre ; the new choir of the sixteenth century altogether dwarf's the tower of the twelfth. These late buildings, in which, for the most part, general mediæval ideas and general mediæval proportions are combined with every kind of mixture of mediæval and Renaissance detail, form a very curious study. In England we are used to this style in houses; we seldom see it in churches, never in churches on any great scale. But in France, where the break between past and present happened late in the eighteenth century instead of in the middle of the sixteenth, churchbuilding went on much later than in England, and this curious class of churches is the result. Many of them are really very fine buildings; the style perhaps reaches its highest point in the great Saint Eustace at Paris, where all the feeling of a Gothic minster is kept without a single good Gothic detail. Here at Saint Eusebius the mixture takes a singular shape. The arcades and clerestory mean to be Gothic ; the triforium between them, a by no means inelegant piece of work but quite incongruous with the stages above and below, belongs to that kind of Renaissance which is in fact a falling back on the more classical types of Romanesque. It would hardly be out of place at Pisa or at Ragusa.

Saint Peter's church at Auxerre, all but the lofty tower, is throughout another example of this mixed style of the seventeenth century, stately in its general effect, but far less interesting than this small piece at Saint Eusebius. But it is curious to see at this late date the Corinthian capitals, some fully finished, some half cut out, some left wholly in the block, just as we might have seen them a thousand years or more earlier. And in front of the church is a Renaissance gateway, which I must confess cost me a second glance before I felt quite certain that I was not looking on an unusually well preserved fragment of old Autessiodurum. 
And now it may be thought that I have been making a comparison between the churches of Sens and Auxerre in which the suffragan see is made undutifully to lift itself up above its metropolis. But let us leave the ecclesiastical side of the two cities; let us go back to days when, when there were bishops either at Sens or at Auxerre, those bishops ran a daily chance of becoming martyrs. Here Sens has her revenge. We may put the difference epigrammatically; Sens still remains Civitas Senonum; Auxerre has long ceased to be Autessiodurum. I mean that from Auxerre, as far as the general look of the city is concerned, all traces of the Roman enclosure have passed away. Its extent is known; when the lines have been once pointed out on a plan, it is not hard to follow them, on two sides at least. in the present streets. The place of the western gate is marked by the mediæval clock-tower of the city, whose look, now that it is so cruelly shorn of the spire which once crowned it, has been already spoken of. This Roman enclosure lay on the slope of the hill, and by no means reached its top. It took in the cathedral church with its surroundings, and the castle of the counts of Auxerre, now represented, in its site though in no other way, by the modern Hôtel de Ville. It took in also several smaller churches clustering round the great one, two of which bore the speaking names of Saint Peter in the Castle and Our Lady of the City. At Auxerre, as elsewhere, from Athens onwards, the name City specially clave to the oldest enclosure. That enclosure left out the abbey of Saint German, and the other churches of Saint Eusebius and the greater Saint Peter. The modern boulevards mark the site of a far later wall, which takes in all these churches, and of which large portions, including several towers, remain. But the old lines of Autessiodurum do not show themselves above ground. They must be traced in vaults and cellars under the houses. Many fragments of the old city have at different times been brought to light, and may now be seen in the museum. Above all, there is one noble capital of the type in which the artists ventured to forsake conventional restrictions, and to bring in living forms, animal, human, and divine. Its fellows may be seen at Rome, in the Tabularium on the Capitol and in 
the baths of Antoninus. Its remote descendants may be seen at Lucca, Nevers, and Wetzlar.

The cause of this difference is that the old Autessiodurum was but a small city, and that mediæval Auxerre greatly outstripped its bounds. But the Roman walls of Civitcis Senonum took up, as became the head of the tribe, a far greater space, and with that space the city proper has been content to this day. The modern boulevards follow the line of the Roman walls; beyond them there is a good deal of suburb. but nothing but suburb. And on one side, the southern side, the remains of the Roman wall form one of the most striking and living bits of history which it has ever been my lot to come across in the shape of brick and stone. As we walk down from the south-eastern corner, the sight grows upon us; we feel more and more at every step that we are compassing one of the great seats of Gaulish and Roman power. We first mark here and there a few mighty stones ; gradually, as we go on, we take in their full force and meaning. Here is a wall of huge stones, of the noblest Roman masonry, which has clearly been patched up in some later repair in the style of Roman work more usual in Gaul and Britain, the ranges of small square stones banded together with linyers of brick. The great stones are no mere foundation for the less massive superstructure. They rise irregularly to different heights, and they have everywhere been made good in the other style. It is plain that a wall of the grandest type that the masons of the elder Empire could put together has been broken down, and repaired in that later Roman style with which we are most familiar, but which is never found in Rome itself. To overthrow such a wall must have been at least as hard a task as to build it; but the task has plainly been gone through. It is clear that the wall of massive stones needed to be made good, and it was made good in what, when we see the two side by side, we cannot help calling an inferior manner. When was the work done? The invasions and tumults and civil wars of the third and fourth centuries allow plenty of opportunities both for destruction and for rebuilding. Jublains remains as an example of a Roman town forsaken in the third century and never rebuilt. 
Sens seems to give us an example of a town which underwent some fearful blow, but a blow from which it recovered. The men of Sens again built up their waste places while the Roman power in Gaul still lasted. The difference between the earlier and the later work is most striking. The contrast between the Titanic grandeur of the older masonry and the later repair that stands against it, makes us grasp more fully the truth that such Roman work as we have in Britain mostly belongs to the later days of Roman occupation.

Whether the wall of Sens is to be looked on as a monument of greater interest than the metropolitan church is largely a matter of personal taste. There can be little doubt which monument is the more striking and unique. I can only speak for myself; I was certainly disappointed in the cathedral ; I was assuredly not disappointed in the wall. Sens, we might say, still remains a Roman city sheltering mediæval and modern work within it. Auxerre is a mediæval city of a very high degree of interest. But its connexion with earlier days is matter of faith and of inference. That Auxerre was a Roman city we know; if we did not know it, we could safely infer the fact from the general history of Gaul. But it does not bear upon it the same lively impress of the presence of the universal conqueror which Sens bears. At Auxerre we see a city of noble churches, associated with great names in ecclesiastical history. At Sens we see the tale told by the Augustan historians, by Ammianus and the Panegyrists, graven, as long as man's works can hope to last, on the stones and bricks which are still alive to tell it. 